\title{
A Southern Stewardship: The Intellectual and the Proslavery Argument
}

\section{Citation}

Faust, Drew Gilpin. 1979. "A Southern Stewardship: The Intellectual and the Proslavery Argument." American Quarterly 31 (1): 63.

\section{Published Version}

doi: $10.2307 / 2712487$

\section{Permanent link}

http://nrs.harvard.edu/urn-3:HUL.InstRepos:12013312

\section{Terms of Use}

This article was downloaded from Harvard University's DASH repository, and is made available under the terms and conditions applicable to Other Posted Material, as set forth at http:// nrs.harvard.edu/urn-3:HUL.InstRepos:dash.current.terms-of-use\#LAA

\section{Share Your Story}

The Harvard community has made this article openly available.

Please share how this access benefits you. Submit a story.

Accessibility 


\title{
A SOUTHERN STEWARDSHIP: THE INTELLECTUAL AND THE PROSLAVERY ARGUMENT
}

\author{
DREW GILPIN FAUST
}

University of Pennsylvania

THE SOUTH'S SYSTEMATIC DEFENSE OF SLAVERY IN THE THREE decades before the Civil War has long puzzled historians. Yet the very distastefulness of the proslavery argument has intrigued modern scholars, who have sought to understand how writers and thinkers-individuals in many ways like themselves-could turn their talents to such abhorrent purpose. But we have too long regarded the proslavery argument either as an object of moral outrage or as a contributing cause of the Civil War. For those who elaborated its details, it had a different meaning. To understand how slavery's apologists came to embrace conclusions we find unthinkable, we must look beyond the polemics of the slavery controversy.

Many of the bewildering aspects of the defense of slavery are best understood as expressions of the special needs of an alienated Southern intellectual class concerned with questions more far-reaching, yet in some ways more immediately personally relevant, than the rights and wrongs of human bondage. The Southern man of mind did not doubt that slavery was a social good that could be supported by rational argument. But in taking up the public defense of the peculiar institution, he sought as well to advance his particular values and to define for himself a respected social role within a culture known for its inhospitality to letters.

Antebellum Southerners themselves recognized that the proslavery argument would achieve little in the ideological warfare between the sections. "We think it is hardly to be expected," one proslavery theorist conceded in 1843, "that anything which can be said at this late date . . . will at all diminish the wrongheaded fanaticism and perverse intolerance of the Northern Abolitionists." This essayist's avowed aim was to do 
"good service within our borders"; other defenders of slavery similarly hoped to "fix" the peculiar institution "infinitely more firmly in the public opinion" of their own section. The importance of the proslavery argument, these Southerners suggest, lay within Southern civilization itself. ${ }^{1}$

The proslavery argument thus raises issues that make it more than just another of the peculiarities of the perennially enigmatic South; it must not be seen merely as evidence of how different the Old South had become from the rest of the nation. In their attempt to create a rational justification for the peculiar institutions of their section, slavery's defenders revealed not only the world view of the South's intellectual class, but demonstrated the existence of widespread similarities in outlook among thinkers on both sides of the Mason-Dixon line. The proslavery argument rested on intellectual values and moral-philosophical assumptions shared throughout mid-nineteenth-century America.

A number of twentieth-century historians have sought to locate the significance of the defense of slavery in the interaction among different groups within the antebellum South. In 1936, William B. Hesseltine explained the movement as part of an effort by the upper-class planter to win the nonslaveholder to his side. More recent scholars such as Charles G. Sellers, Jr. and Ralph E. Morrow have characterized the argument as an attempt by slaveholders to establish peace not with other groups but with themselves, by alleviating feelings of guilt created by nagging contradictions between slavery and America's democratic creed. Although both these explanations seem plausible, there is little evidence to support either. Overt expression of class resentment or antagonism was rare in the Old South; planters' personal papers express few pangs of conscience about the Southern system. ${ }^{2}$

${ }^{1}$ [George Frederick Holmes], "On Slavery and Christianity," Southern Quarterly Review, 3 (Jan. 1843), 252; James Henry Hammond to Nathaniel Beverley Tucker, Feb. 23, 1849, Tucker-Coleman Collection, Earl Gregg Swem Library, College of William and Mary, Williamsburg, Va. William Gilmore Simms expressed his concern with using the proslavery argument to counteract the indifference of "our people of the South" in regard to slavery's defense. Simms to Hammond, Apr. 10, 1845, Mary C. S. Oliphant et al., eds., Letters of William Gilmore Simms, 5 vols. (Columbia, S. C.: Univ. of South Carolina Press, 19521956), 2: 50-51. On the South's general inhospitality to letters see Clement Eaton, The Freedom-of-Thought Struggle in the Old South (New York: Harper and Row, 1964).

${ }^{2}$ Hesseltine, "Some New Aspects of the Pro-Slavery Argument," Journal of Negro History, 21 (Jan. 1936), 1-14; Morrow, "The Proslavery Argument Revisited," Mississippi Valley Historical Review, 48 (June 1961), 79-94; Sellers, "The Travail of Slavery," in Sellers, ed., The Southerner as American (Chapel Hill: Univ. of North Carolina Press, 1960), 40-71. For other proponents of this view see William W. Freehling, Prelude to Civil War: The Nullification Controversy in South Carolina, 1816-1836 (New York: Harper and Row, 1966); and James M. McPherson, "Slavery and Race," Perspectives in American History, 3 (1969), 460-73. 
While Sellers, Hesseltine, and Morrow accurately characterized the defense of the peculiar institution as a manifestation of stress within Southern society, they did not seek to relate these tensions to the social locations of the apologists themselves. In 1970, however, David Donald began to explore the social origins of some of slavery's most prominent defenders. "All," he found, "were unhappy men" compensating for "severe personal problems relating to their place in Southern society." Their proslavery tracts, he concluded, displayed a longing to escape this crisis of social identity by returning to a "by-gone pastoral Arcadia," to a world they had lost. Slavery's defenders, Donald contended, shared a pervasive "sense of alienation." 3

These feelings of distance from the contemporary world are evident throughout proslavery writings. But they did not represent a defensive and hopeless nostalgia. Many proslavery advocates were highly critical of the region whose peculiar institution they had set forth to justify, and they were far from consistently backward-looking in their views. James Henry Hammond and William Gilmore Simms, two of Donald's prominent examples, directly opposed the control that South Carolina's traditionbound aristocracy exerted within the state. And instead of seeking a "pastoral Arcadia," a number of these Southern apologists followed the lead of James D. B. De Bow in urging the development of industrial and commercial enterprise to reduce dependence on the North. ${ }^{4}$

The dissatisfaction Donald identified as characteristic of slavery's defenders arose less from a desire to escape the present than from what he identified as anxieties "relating to their place in Southern society." But Donald's essay does not make the source of these tensions clear, for, as

\footnotetext{
${ }^{3}$ Donald, "The Proslavery Argument Reconsidered," 12, 16. Donald's interpretation of slavery's defenders seems to fit within the genre of "status-anxiety" interpretationsexplanations of ideologies and social movements as the result of concern about changing, usually diminishing social status. Although he does not explicitly refer to "status-anxiety" in the essay on proslavery, this framework seems implicit, as, for example, in his references to Edmund Ruffin as "frustrated," to J. D. B. De Bow as "compensating" for his lack of social position and to W. G. Simms as worrying about his location "on the fringes of society." Ibid., 10-11. For a similar treatment of antislavery, see Donald, "Toward a Reconsideration of Abolitionists," in Donald, Lincoln Reconsidered: Essays on the Civil War Era (New York: Knopf, 1956), 19-36.

${ }^{4}$ Donald, "The Proslavery Argument Reconsidered," 17n. For a discussion of the views of Simms, Hammond, George Frederick Holmes, Nathaniel Beverley Tucker, and Edmund Ruffin on these issues see Drew Gilpin Faust, A Sacred Circle: The Dilemma of the Intellectual in the Old South, 1840-1860 (Baltimore: Johns Hopkins Univ. Press, 1977). Fitzhugh also encouraged economic diversification. See, for example, "Make Home Attractive," De Bow's Review, 28 (June 1860), 624. On De Bow as an advocate of industry see Ottis C. Skipper, J. D. B. De Bow, Magazinist of the Old South (Athens: Univ. of Georgia Press, 1958); and the James Dunwoody Brownson De Bow Letters and Papers, Manuscript Division, William Perkins Library, Duke Univ.
} 
his article indicates, proslavery advocates came from widely varied social positions. Hammond, for example, was descended from New England stock of no particular distinction and recognized that he had "sprung up from amongst the great undistinguished mass of the people." Indeed, journalist De Bow cited the later wealth and prominence of the Carolinian as living proof of the reality of social mobility within the region. Simms, son of a bankrupt Irish immigrant, and James Henley Thornwell, whose father was an overseer, similarly felt themselves strangers to the South Carolina elite. Like Hammond, they hoped to gain places to which birth gave them little claim. By contrast, other apologists for slavery came from more elevated social positions. Edmund Ruffin, George Fitzhugh, and Nathaniel Beverley Tucker, for example, were descended from Virginia's finest blood, and they might accurately be described as aristocrats of declining status. ${ }^{5}$

These objective differences among the lives of slavery's defenders suggest the need to explain the social context of their ideas in more complex terms than simple movement up and down within the social hierarchy. Although Ruffin's and Tucker's social status may have been in some sense declining, while Hammond's, Simms', and Thornwell's were rising, these men shared feelings of anxiety about the very uncertainty of their situations. And this uncertainty arose not so much from objective economic or class position as from their own conception of themselves and their role in Southern society. Slavery's defenders were the South's intellectuals. Authors of proslavery tracts were not for the most part the

\footnotetext{
${ }^{5}$ Hammond to Colonel H. Caughman, Dec. 29, 1833, James Henry Hammond Papers, Manuscript Division, Library of Congress, hereafter cited as Hammond Papers, LC. De Bow discusses Hammond in The Interest in Slavery of the Southern Non-Slaveholder; The Right of Peaceful Secession; The Character and Influence of Abolitionism (Charleston: Evans and Cogswell, 1860), 10. The issue of Simms' origins is complex. His nineteenthcentury biographer William Peterfield Trent stressed Simms' lowly origins, but later scholars have found Trent's descriptions exaggerated, for they point to one of Simms' ancestors who fought in the Revolution and another who was a sizable landholder. Simms' position was unclear to himself as well as to his numerous biographers. Unquestionably, however, he perceived himself to be very distant from the traditional South Carolina elite. See Trent, William Gilmore Simms (Boston: Houghton Mifflin, 1892); John R. Welsh, Jr., "The Mind of William Gilmore Simms: His Social and Political Thought,"' Diss. Vanderbilt Univ. 1951; and Jon L. Wakelyn, The Politics of a Literary Man: William Gilmore Simms (Westport, Ct.: Greenwood Press, 1973), 3. On Thornwell see the James Henley Thornwell Papers, South Caroliniana Library, Univ. of South Carolina, hereafter cited as SCL; and Benjamin M. Palmer, The Life and Letters of James Henley Thornwell (Richmond: Whittet and Shepperson, 1875). On Ruffin see the Edmund Ruffin Papers, LC, the Edmund Ruffin Papers, Virginia Historical Society (hereafter VHS), Richmond, Va., and Avery O. Craven, Edmund Ruffin, Southerner: A Study in Secession (1932; rpt. Baton Rouge: Louisiana State Univ. Press, 1966). On Tucker see the Tucker-Coleman Collection and Robert J. Brugger, Beverley Tucker: Heart over Head in the Old South (Baltimore: Johns Hopkins Univ. Press, 1978).
} 
South's largest slaveholders, nor were they compensating for not occupying this particular highly-valued status. Rather, these individuals were college professors, ministers, writers, journalists, and others who defined themselves primarily in terms of their mental gifts and undertook the defense of slavery as but one of a variety of intellectual ventures. The frustrations which Donald identifies arose above all from their perception of themselves as men of mind in a society which accorded little importance to abstract speculation and rendered intellectual endeavor about as rewarding, Simms remarked, as "drawing water in a sieve." 6

This Southern intelligentsia was so small that a surprising number of defenders of the peculiar institution had come to know one another even before they launched their proslavery crusade. Thomas Roderick Dew, author of the first famous "positive good" argument was, for example, a colleague and close friend of Nathaniel Beverley Tucker's at William and Mary. Tucker in turn corresponded regularly with other such prominent proslavery apologists as George Frederick Holmes, Edmund Ruffin, Abel Parker Upshur, William Gilmore Simms, and James Henry Hammond. Hammond was intimate with both Ruffin and Simms, as well as with self-styled ethnologist Josiah Clark Nott, author Augustus Baldwin Longstreet, and his own former legal mentor, Chancellor William Harper, author of the widely read Memoir on Slavery and cousin to both Tucker and Holmes. Holmes corresponded with Simms, Thornwell, De Bow and George Fitzhugh, and served on the faculties of both the University of Virginia and the University of Mississippi with Albert Taylor Bledsoe. ${ }^{7}$ The ties among slavery's apologists were so extensive and intertwined that they are perhaps better illustrated on the following chart than described in words. To take the place of the intellectual institutions the South lacked, these men of mind created an "invisible college" that

${ }^{6}$ Simms to Hammond, May 10, 1845, Oliphant et al., eds. Letters, 2, 61. For a compilation and analysis of 275 defenders of slavery, North and South, between 1701 and 1865 see Larry E. Tise, "Proslavery' Ideology: A Social and Intellectual History of the Defense of Slavery in America, 1790-1840," Diss. Univ. of North Carolina 1975.

${ }^{7}$ See Dew, Review of the Debate in the Virginia Legislature of 1831 and 1832 (Richmond: T. W. White, 1832) and the Dew Family Papers, Earl Gregg Swem Library, College of William and Mary; the Edmund Ruffin Papers, VHS; Thornwell Papers; George Frederick Holmes Papers, Manuscript Division, LC; George Frederick Holmes Papers, Manuscript Division, William Perkins Library, Duke University; De Bow Letters and Papers; Augustus Baldwin Longstreet Papers, SCL; Albert Taylor Bledsoe Papers, Manuscript Division, LC; William Porcher Miles Papers, Southern Historical Collection, Univ. of North Carolina, Chapel Hill. There are numerous Nott-Hammond letters in the Hammond Papers, LC and Upshur-Tucker letters in the Tucker-Coleman Collection. On the particularly intimate relationship among Hammond, Simms, Ruffin, Tucker, and Holmes see Faust, A Sacred Circle . 


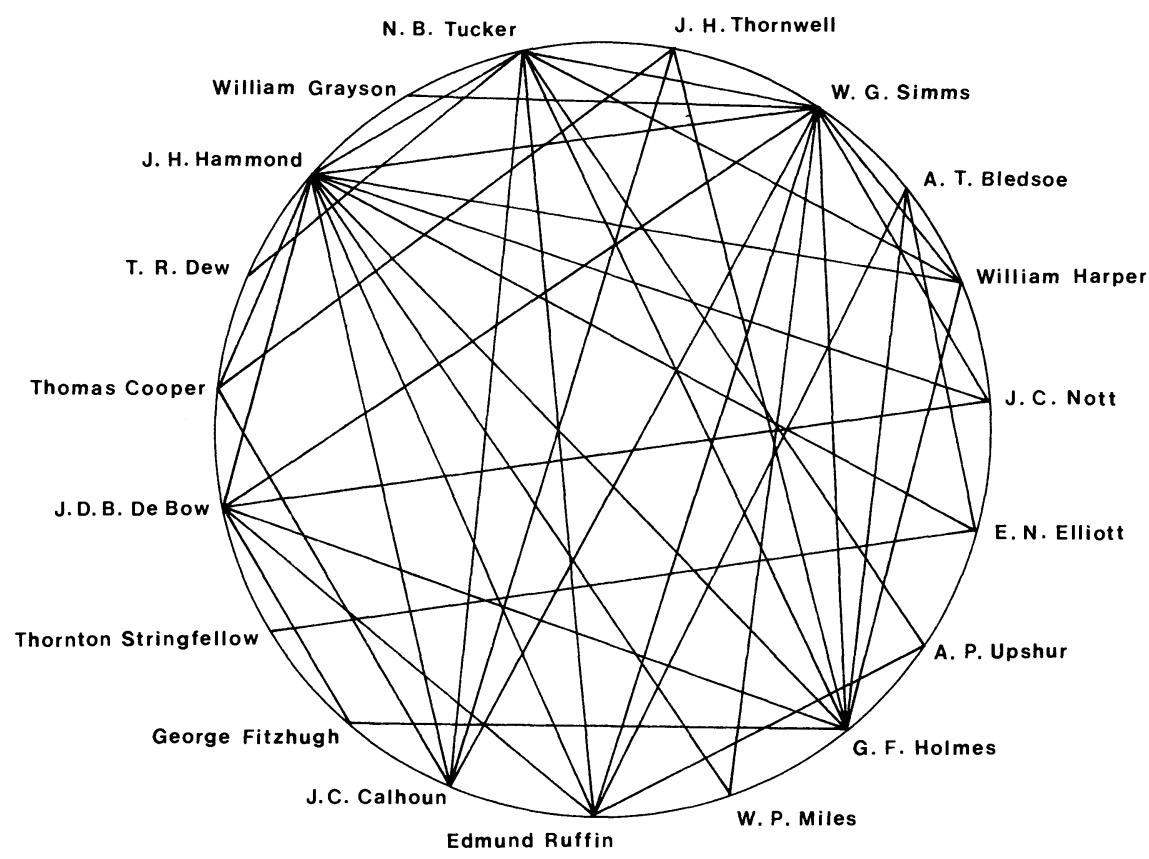

PERSONAL INTERACTIONS AMONG SLAVERY'S DEFENDERS

served as a vehicle for the exchange of ideas and the provision of mutual support. ${ }^{8}$

One area of agreement-and concern-among these thinkers was the sorry state of intellectual endeavor in the region. Southern literary periodicals, they complained, seemed inevitably to fail; regional publishing facilities were inadequate; Southern colleges, George Frederick Holmes charged, were often institutions of higher learning only "in name." The South had become a land, Virginian Thornton Stringfellow remarked, "defiled with ignorance." Though "The first care of a State," William Harper observed, ought to be to "provide minds of extraordinary power ... [with] the means ... . for their most consummate cultivation," the South seemed to exhibit what Hugh Swinton Legare perceived as a decided "prejudice against bookish men.", 9

${ }^{8}$ On "invisible colleges" as a form of organization and interchange in scientific communities see Diana Crane, Invisible Colleges: Diffusion of Knowledge in Scientific Communities (Chicago: Univ. of Chicago Press, 1972).

${ }^{9}$ George Frederick Holmes to Lavalette Floyd Holmes, June 15, 1846, Holmes Papers, Duke; Thornton Stringfellow, Richmond Religious Herald, February 25, 1841; William 
But the common plight that they shared as thinkers in such a region appeared to these individuals as a problem of more than just personal social import. The neglect of the intellectual, they believed, was simply one manifestation of much broader processes of cultural and moral change engulfing their mid-nineteenth-century world; a crisis of belief seemed to challenge the foundations of all truth. Alarming social developments grew directly out of a declining faith in traditional moral and intellectual authority. The difficulties that the South confronted in the late antebellum period were only particular examples of these widespread failings. Political corruption, Abel Upshur proclaimed, grew out of the region's failure to provide its citizenry with the moral education that would transform them from politicians into statesmen. The causes of soil erosion, Ruffin similarly concluded, "may be summed up in the single word, ignorance." Simms agreed, declaring that the only salvation for agriculture, and for the South as a whole, lay in "the loyalty of . . . [the] people to their leading intellects." In jeremiads against their region the men of mind assailed the South's multifarious shortcomings as the result of her neglect of transcendent moral concerns and of those individuals whose superior minds best equipped them to defend such principles. ${ }^{10}$

Regarding themselves as rightful custodians of truth and scientists of morals, these Southern thinkers set out to claim their appointed social place; they would reform the degenerate South, convert her to a respect for abstract principles and scientific speculation, and in so doing, convince her to recognize their particular moral and intellectual talents. These thinkers thus became involved in a variety of endeavors directed at regional improvement. Some, like Ruffin, became prophets of agricultural rationalism; others, like Hammond and De Bow, advocated economic diversification. Dew and Stringfellow flirted in the earlier decades of the movement with temperance; Simms called on his friends to aid in the creation of a Southern literature; Holmes and Henry Hughes in turn dedi-

Harper, "Slavery in the Light of Social Ethics," in E. N. Elliott, ed., Cotton Is King and Pro-Slavery Arguments (Augusta: Pritchard, Abbot and Loomis, 1860), 577; Legare, quoted in Linda Rhea, Hugh Swinton Legare, A Charleston Intellectual (Chapel Hill: Univ. of North Carolina Press, 1934), 77. On Stringfellow see Faust, "Evangelicalism and the Meaning of the Proslavery Argument: The Reverend Thornton Stringfellow of Virginia," Virginia Magazine of History and Biography, 85 (Jan. 1977), 3-17.

${ }^{10}$ References in this paragraph are in order from Upshur, "Domestic Slavery," Southern Literary Messenger, 5 (Oct. 1839), 677-87; Claude H. Hall, Abel Parker Upshur, Conservative Virginian, 1790-1844 (Madison: Univ. of Wisconsin Press, 1963), 110; Ruffin, "Sketch of the Progress of Agriculture in Virginia and the Causes of Decline and Present Depression: An Address to the Historical and Philosophical Society of Virginia," Farmers' Register, 3 (Apr. 1836), 754; [Simms], "Agriculture in South-Carolina," Magnolia, 2 (Mar. 1843), 201. 
cated themselves to a reform of knowledge-a new Baconian instauration which would establish scientific truths about the social order and thus guide human progress. ${ }^{11}$

No area of reformist interest was exclusively the concern of any single intellectual, but the issue on which all converged was what they called the "philosophical" defense of slavery. Because of its combined moral and social import the problem of slavery seemed logically to belong to men of intellectual and moral superiority. Only such individuals could evaluate the peculiar institution in accordance with the principles of science and religion that formed the basis of all truth. On this issue, as in all the thinkers' concerns, the tenets of moral philosophy would structure their outlook. Moral science, which formed the central component in the midnineteenth-century intellectual world view and served as the capstone of every college career, would provide the foundation of slavery's defense. ${ }^{12}$

The imagery and vocabulary of the proslavery argument offer the most striking evidence for its origins in the needs of the Southern intellectual. The thinkers' apologies served to define their particular system of values as the best justification for the section's most distinctive and important institution. In the proslavery argument the cause of intellect became united with the cause of the South. The region's need for a plausible social philosophy, George Frederick Holmes recognized, would make the South regret her past failures to accord "material support and public favor" to learning. "[W]e shall be indebted," Holmes anticipated, "to the continuance and asperity of this controversy for the creation of a genuine southern literature ...." ${ }^{13}$ Rather than the product of a social or economic elite, the proslavery argument was the creation of an intellectual class seeking to prove itself indispensable in defending the South's peculiar way of life.

\footnotetext{
${ }^{11}$ Ruffin, An Essay on Calcareous Manures (Shellbanks, Va., 1835); Ruffin, Essays and Notes on Agriculture (Richmond, 1855); Simms, "Southern Literature," Magnolia, 3 (Feb. 1841), 69-74; [Holmes], "Philosophy and Faith," Methodist Quarterly Review, 33 (Apr. 1851), 187. On Henry Hughes see Bertram Wyatt-Brown, "Modernizing Southern Slavery: The Proslavery Argument Reinterpreted," unpublished manuscript lent by the author. On Stringfellow see Faust, "Evangelicalism and the Meaning of the Proslavery Argument."

${ }^{12}$ Moral philosophy served as what Norman S. Fiering has called a "semi-secular way station" between a world of faith and one of science. It was designed to demonstrate the compatibility of reason and religion by marshaling science in support of morality. Fiering, "President Samuel Johnson and the Circle of Knowledge," William and Mary Quarterly, 3d Ser., 28 (Apr. 1971), 233. On moral philosophy generally see Donald H. Meyer, The Instructed Conscience: The Shaping of the American National Ethic (Philadelphia: Univ. of Pennsylvania Press, 1972).

13 [Holmes], "Uncle Tom's Cabin," Southern Literary Messenger, 18 (Dec. 1852), 725; [Holmes], "Bledsoe on Liberty and Slavery," De Bow's Review, 21 (Aug. 1856), 133. On Holmes' more general views see Neal C. Gillespie, The Collapse of Orthodoxy: The Intellectual Ordeal of George Frederick Holmes (Charlottesville: Univ. of Virginia Press, 1972).
} 
The desire to legitimate their own social aspirations may make these intellectuals' professed idealism seem transparently self-serving. But every belief system functions in this manner. An individual embraces a particular configuration of ideas because it appeals to his emotional and social as well as his cognitive needs. These Southerners felt both culturally and socially adrift; they confronted an irreducible human need for meaning, for a solid foundation for truth and value in a world beset by doubt. This crisis of belief was no less personally important to them than the social dilemmas that seemed to be its direct product. Indeed, to Beverley Tucker, it appeared remarkable that "my ambition and my convictions coincide." 14

Designed to provide legitimacy for the Southern man of mind and his values, the defense of slavery had in substance and method to meet the criteria of objectivity which he believed characterized all intellectual endeavor; it must be without passion or prejudice. Discussion of the peculiar institution, Albert Taylor Bledsoe urged, should be based "upon purely scientific principles," with "no appeal to passion or to sordid interest." E. N. Elliott, editor of the proslavery anthology Cotton Is King, boasted that Southern apologists did not stoop to the "vituperative denunciation," "gross exaggerations and . . . willful falsehoods" that characterized abolitionist tracts. Slavery's defenders, he observed, maintained the "spirit, tone and style of . . . Christian candor and fairness of argument that should characterize the search after truth. . . " The examination of slavery, Holmes agreed, must be "removed from the domain of sectional controversy and political warfare ... to the more temperate and authoritative tribunal of sober and cautious reflection"; it must, in other words, become the province of the intellectual. ${ }^{15}$

Like most scholarly inquiries of the mid-nineteenth century, this search for truth began with the Bible. In the Old Testament, divine intentions seemed unmistakable, for God's chosen had been a slaveholding people. Christ made no attack on slavery in the New Testament, and his apostle Paul had explicitly recognized it to be consistent with Christian principles. But for an age increasingly enamored of the vocabulary and methods of natural science Biblical guidance was not enough. Man could and must determine his moral duties scientifically as well by examining the progres-

${ }^{14}$ Tucker to Hammond, May 7, 1850, Hammond Papers, LC.

${ }^{15}$ Bledsoe, "Liberty and Slavery: or, Slavery in the Light of Political Philosophy," in Elliott, ed., Cotton Is King, 274; Elliott, "Concluding Remarks," ibid., 897; [Holmes], "Failure of Free Societies," Southern Literary Messenger, 21 (Mar. 1855), 129; "Aristotle on Slavery," MS., Holmes Papers, LC. On the substance of the proslavery argument the classic work is William S. Jenkins, Pro-Slavery Thought in the Old South (Chapel Hill: Univ. of North Carolina Press, 1935). 
sive revelation of God's designs in history, which would provide, as Holmes observed, the needed "basis of our inductions"' about the proper social order. The study of human bondage would be empirical-in the words of the Reverend Thornton Stringfellow, at once "Scriptural and Statistical"; the proslavery argument would meet the positivistic standards the nineteenth-century intellectual was coming to accept for assessment of all social problems. A defense of slavery would essentially be, as Henry Hughes explicitly defined it, a Treatise on Sociology. Like conservatives throughout the nation, proslavery thinkers would call for an empirical science of society to counteract the dangerous abstractions of abolitionism and other ill-supported theories of social reform. Social facts, which Calhoun found "as unquestionable as . . . gravitation or any other phenomenon of the material world," would best reveal both divine and natural purpose. ${ }^{16}$

History inevitably served as one vehicle for empirical investigation into the problem of human bondage. From Greece and Rome to the American South, these thinkers proclaimed, slavery had served as the foundation of all great civilizations. The "continued duration of the institution . . . its almost universal extension" seemed to Edmund Ruffin irrefutable evidence that it was "established by God." 17

Implicit in this appeal to history as a catalogue of social experiments lay a challenge to the concepts of natural law that had been established as fundamental American principle at the time of the Revolution. Social law as revealed in history made clear that men had not in reality been created equal and free, as Jefferson had asserted. Nature produced individuals strikingly unequal in both qualities and circumstances. Simms argued that a truly natural right was "not intended to make the butcher a judge, or the baker a president; but to protect them, according to their claims as butcher and baker." Conformity with scientific realities prescribed a

${ }^{16}$ [Holmes], "Observations on a Passage in the Politics of Aristotle Relative to Slavery," Southern Literary Messenger, 16 (Apr. 1850), 197; Hughes, Treatise on Sociology: Theoretical and Practical (Philadelphia, 1854). For what Hammond called the "best scriptural argument" for slavery see Thornton Stringfellow, Scriptural and Statistical Views in Favor of Slavery (Richmond: J. W. Randolph, 1856) cited in Hammond to Simms, June 11, 1852, Hammond Papers, LC. John C. Calhoun, A Disquisition on Government (1853; rpt. New York: Bobbs-Merrill Co., 1953), 3.

${ }^{17}$ Ruffin, Address to the Virginia State Agricultural Society, on the Effects of Domestic Slavery ... (Richmond: P. D. Bernard, 1853), 19. On slavery and history see Hammond, "Hammond's Letters on Slavery," in The Pro-Slavery Argument; as Maintained by the Most Distinguished Writers of the Southern States . . . (Charleston: Walker, Richards, 1852), 154; Ruffin, The Political Economy of Slavery; or, The Institution Considered in Regard to its Influence on Public Wealth and the General Welfare (Washington: L. Towers, 1857), 3; [Holmes], "Slavery and Freedom," Southern Quarterly Review, 1 (Apr. 1856), 86. 
hierarchically structured society reproducing nature's orderly differentiations. The Revolutionary concepts of natural law were thus transmuted into the tenets of social organicism; the prestige of modern science served to legitimate tradition and conservatism. ${ }^{18}$

Redefining natural rights necessitated a redefinition of freedom. Despite its "transcendent importance," Bledsoe found that liberty had "been, for the most part, a theme for passionate declamation, rather than of severe analysis or of protracted and patient investigation." True freedom was not just the absence of restraint. Rather it had a more positive aspect. A man was most free, Simms declared, when permitted "to occupy his proper place. He, only, is the slave, who is forced into a position in society which is below the claim of his intellect and moral." Southern slavery was merely a benevolent institutionalization of these principles of inherent inequality. "Fed, clothed, protected," the slave, William J. Grayson proclaimed, was far better off than the Northern operative whose employer had no interest in his health or even his survival. "Free but in name," Northern laborers had liberty to starve. The Southern thinkers agreed with Chancellor Harper that there existed "some form of slavery in all ages and countries." The Southern system of human bondage simply structured this interdependence in accordance with the principles of morality and Christianity. The humanitarian arrangements of slavery, the Southerners proclaimed, contrasted strikingly with the avaricious materialism of the "miscalled" free society of the North. While the Yankees cared only about the wealth their operatives might produce, Southerners accepted costly responsibility for the lives of the human beings God had "entrusted" to them. A number of defenders even maintained, like Harper, that "slave labor can never be so cheap as what is called free labor." Nevertheless, Hammond piously advised, slavery's moral purposes dictated that "We must . . . content ourselves with . . . the consoling reflection that what is lost to us, is gained to humanity. . . ." In the proslavery argument, the Southern intellectual asserted his opposition to the growing materialism of the modern age. ${ }^{19}$

\footnotetext{
${ }^{18}$ Simms, "The Morals of Slavery," in The Pro-Slavery Argument, 256. See Hammond's manuscript on "Natural Law" which he sent to Tucker, Tucker-Coleman Collection, and also his repudiation of Jefferson in "Hammond's Letters on Slavery," 110; see also Bledsoe, "Liberty and Slavery,"' 271.

19 Bledsoe, "Liberty and Slavery," 273; Simms, "The Morals of Slavery,"' 258; Grayson, "The Hireling and the Slave," in Eric L. McKitrick, ed., Slavery Defended: The Views of the Old South (Englewood Cliffs, N. J.: Prentice-Hall, 1963), 57-68 (quotations on pp. 66, 68); Harper, "Slavery in the Light of Social Ethics," in Cotton Is King, 553, 569; Hammond, "Hammond's Letters," 122. See also [Holmes], "Slavery and Freedom," 84, for a similar remark.
} 
When these thinkers declared, as they frequently did, that domestic slavery was "the basis of all our institutions," the foundation they envisioned was preeminently moral rather than economic or political. Their particular values seemed realized in the idealized system of bondage they portrayed. Duty and responsibility, not avarice, linked master and slave; the seemingly scientific criteria of racial differentiation structured society; men of superior mind exercised leadership and authority. ${ }^{20}$

Yet these intellectuals' repeated criticisms of the South for its moral failures indicate that slavery's defenders recognized that this portrait of the region reflected their hopes and fears more than reality. They sought ultimately not to describe the South but to inspire it. The only way to legitimate slavery, their arguments implicitly warned, was to transform the region into the moral utopia of their essays. The proslavery argument was fundamentally a charter for reform.

This movement to revitalize the South was founded in a commitment to stewardship as the region's essential social relationship. The master was God's surrogate on earth; the structure of Southern society replicated the order of the divine cosmos. Slavery encouraged Christian values in whites and served as a missionary institution for bondsmen. To defend slavery was therefore, as Simms described it, "a sacred duty," clearly comprehended within the concerns of men of special intellectual and moral insight. ${ }^{21}$ The Southern system institutionalized the Christian duties of charity in the master and humility in the slave. But at the same time it justified the Southern way of life, stewardship legitimated the thinkers' claims to authority. It was, after all, the "intellectual Caucasian," who, as Tucker observed, "bore the characteristics of his race in the highest perfection," who served as the most natural steward over both whites and blacks. As Simms proclaimed, "the true business of genius" was "to lift and guide" the lesser members of the human race. ${ }^{22}$

Mind would serve, they proposed, as the criterion of all social differentiation. Intelligence rendered blacks unequal to whites and designated them for their lowly status; intelligence, slavery's defenders argued, was the distinguishing characteristic of the white race and evidence of its superiority. By implication, therefore, works of mind were the highest achievements of the race, and the intellectual was its supreme manifestation. The same hereditarian doctrines which justified black enslavement

${ }^{20}$ [Tucker], "Slavery," Southern Literary Messenger, 2 (Apr. 1836), 337.

${ }^{21}$ Simms, "Morals of Slavery," 275.

${ }^{22}$ Tucker, Prescience. Speech Delivered by Hon. Beverley Tucker of Virginia in the Southern Convention Held at Nashville, Tenn., April 13th, 1850 (Richmond: West and Johnson, 1862), 14-15; [Simms], "Headley's Life of Cromwell," Southern Quarterly Review, 14 (Oct. 1848), 507-08. 
legitimated the social aspirations of the genius. In his theories of race, as in his more general social philosophy, the thinker portrayed himself as not just a divinely appointed steward, but the best example of the "intellectual Caucasian"; he was both selected by nature and elected by God. Religion, history, and science combined to justify the debasement of the black and the elevation of the intellectual. ${ }^{23}$

Such a variety of arguments appeared again and again in proslavery tracts. Indeed, these essays generally assumed a stylized form, for there were few challenges to the basic moral-philosophical assumptions of slavery's defenders. Southerners proudly emphasized that all slavery's apologists stood, as E. N. Elliott asserted, "on, substantially, the same ground, and take the same general views of the institution." In its consistency, they believed, rested much of their argument's strength. Even those who tended to emphasize the newly important doctrines of a nascent scientific racism regarded the truths of nature primarily as indicators of God's designs. "All science," Josiah C. Nott proclaimed, "may be regarded as a revelation from Him." There seemed, as the title of one of Nott's proslavery essays declared, to be a direct "Connection Between the Biblical and Physical History of Man. ${ }_{24}$

But relationships within the proslavery movement were not uniformly harmonious. Because Southern intellectuals regarded the argument as a vehicle for their self-definition they felt compelled to dissociate themselves explicitly from discussions of the peculiar institution that seemed incompatible in tone or purpose with their transcendent commitments. This was the basis for the objections which a number of thinkers expressed about William Lowndes Yancey's polemical utterances and even John Caldwell Calhoun's more self-interested actions. Sometimes, Hammond remarked in disgust, Calhoun behaved as if "you have but to say nigger to the South to set it on fire as one whistles to the Turkey to make him gobble." Such use of the proslavery argument as an instrument for political agitation seemed a desecration. ${ }^{25}$

George Fitzhugh, the proslavery writer who has probably attracted most attention from twentieth-century historians, was particularly criticized by many of his contemporaries, and the reasons for this dislike

${ }^{23}$ Tucker, "An Essay on the Moral and Political Effect of the Relation Between the Caucasian Master and the African Slave," Southern Literary Messenger, 10 (June 1844), 332.

${ }^{24}$ Elliott, "Introduction," in Elliott, ed., Cotton Is King, xii; Nott, Two Lectures on the Connection Between the Biblical and Physical History of Man. Delivered by Invitation From the Chair of Political Economy, etc., of the Louisiana University in December 1848 (1849; rpt. Negro Universities Press, 1969), 14.

${ }^{25}$ Hammond to Simms, June 20, 1848, Hammond Papers, LC. See also Hammond, "Thoughts and Recollections," March 28, 1852, Hammond Papers, SCL 
are revealing. Holmes was alarmed because Fitzhugh ignored the scientific requirements for disinterested pursuit of truth and even approached polemic. In Cannibals All! he went so far as to proclaim himself no scholar and to denounce philosophy as a waste of time. To Holmes he confided that he had never read Aristotle, the equivalent in the mid-nineteenth century to admitting himself uneducated. As the two Southerners corresponded between 1854 and 1857 Holmes grew disenchanted with his new acquaintance. When Fitzhugh acknowledged him in the preface to Cannibals All! Holmes complained in his diary, "I dislike notoriety." As Holmes explained, Fitzhugh's "utter recklessness of both statement and expression" made his work "incendiary and dangerous"; he threatened to replace "sober and cautious" reflection on slavery with a literary sideshow. ${ }^{26}$

Moreover, Fitzhugh's ideas contributed little to the crusade. Although he declared himself to be the first to have "vindicated slavery in the abstract," many earlier apologists had taken such a position. Perhaps Dew's 1831 essay was too squeamish to be considered more than a fledgling "positive-good"' argument, for Dew emphasized the implausibility of alternative labor systems more strongly than the excellence of slavery. But by the late 1830s, and well before Fitzhugh began to publish in 1849, Tucker, Simms, Bledsoe, Harper, Upshur, Hammond, Ruffin, Holmes, and others had defended slavery on theoretical grounds, declaring it to be of divine appointment and a benefit to both master and slave. ${ }^{27}$

Eugene Genovese, however, has found Fitzhugh "a ruthless and critical theorist who spelled out the logical outcome of the slaveholders' philosophy and laid bare its essence." Yet Fitzhugh was in many ways atypical and even antithetical to the moral-philosophical mainstream of proslavery thought - not its logical outcome. By the time Fitzhugh began to write, the Southern intellectual class had already outlined the proslavery argument according to its idealist views and would-be social role. Oblivious to these concerns, which determined the substance of proslavery thought and underlay the very arguments he borrowed, Fitzhugh was marginal to the movement. ${ }^{28}$

${ }^{26}$ Fitzhugh to Holmes, Mar. 27, 1855, Letterbook; Fitzhugh to Holmes, Apr. 11, 1855; Holmes Diary, Aug. 9, 1856, Holmes Papers, Duke Univ. Ruffin declared he found Fitzhugh's ideas "foolish," Diary, Oct. 26, 1858, Ruffin Papers.

${ }^{27}$ Fitzhugh to Holmes, Mar. 27, 1855, Letterbook, Holmes Papers; Dew, Review of the Debate, 322.

${ }^{28}$ Genovese, The World the Slaveholders Made: Two Essays in Interpretation (New York: Pantheon, 1969), 129. On Fitzhugh see also C. Vann Woodward, "George Fitzhugh, Sui Generis," in Fitzhugh, Cannibals All! or Slaves Without Masters, Woodward, ed., (Cambridge: Harvard Univ. Press, 1960), vii-xxxix; Harvey Wish, George Fitzhugh: Propagandist of the Old South (Baton Rouge: Louisiana State Univ. Press, 1943); Louis Hartz, 
Genovese, however, is less interested in Fitzhugh's place within the proslavery movement than in his significance within the broader Southern world view. In Fitzhugh's thought, indeed in the values he did share with other apologists, Genovese finds the essence of Southern distinctiveness, the antimaterialist-what he calls anticapitalist and prebourgeoisoutlook upon which Fitzhugh's defenses of slavery rested. Genovese regards these attitudes as the logical product of the particularly Southern relationship between the ownership and the means of production, the master and the slave. Yet these antimaterialist values in large part grew out of the needs of the alienated Southern intellectual class from which Fitzhugh borrowed the moral-philosophical bases for his arguments. And these views did not so much reflect the realities of Southern life as the ambivalence of a group of intellectuals about the changes taking place in their society and throughout the Western world. Ironically, Genovese finds Southern antimaterialism best exemplified in George Fitzhugh, an individual accused by his contemporaries of consciously appropriating these ideas not for their intrinsic merit but for his own fame and material advancement.

Genovese has accurately observed that many Southerners did indeed challenge the preoccupation with the "cash nexus" which they believed characterized much of nineteenth-century America. But slaveholders were not alone in feeling these anxieties. The most striking aspect of the proslavery argument is that the values upon which it depended and the confusions that it reflected were not peculiar to the South. The men of mind who constructed slavery's defense sought a plausible belief system for their society and thus based their arguments upon moral and social values to which large numbers of Americans both North and South could assent. Stewardship, which Genovese defines as the essential principle of the master-slave relationship, was an important characteristic of the evangelicalism which pervaded all of nineteenth-century America. Historians have emphasized its efficacy in the North, where it motivated the myriad reform movements. In explaining the acceptance of "direct social responsibility for others" as the product of a "prebourgeois" Southern world view, Genovese ignores the existence of these central aspects of Northern civilization. The social ideas advanced by the apologists of slavery were shared by many Americans in no way influenced by participation in the master-slave relationship. Indeed, many of these Northern "stewards" were among slavery's harshest opponents. ${ }^{29}$

The Liberal Tradition in America: An Interpretation of American Political Thought Since the Revolution (New York: Harcourt, Brace, 1955).

${ }^{29}$ Genovese, The World the Slaveholders Made, 148, 244. Also see Larry Tise, "Proslavery Ideology," for a consideration of the similarities of ideology, North and South. 
Genovese's analysis of Fitzhugh is ultimately circular, for it defines the South as "prebourgeois" and then points to the single Southerner who openly attacked capitalism as the most accurate exponent of the regional world view. Genovese portrays the tensions within the Southern mind brilliantly, but he errs in his explanation of these anxieties. These strains were not the product of slavery, for they were widespread in the North as well, where the challenge to long-accepted values had produced the multitude of "isms" - from communitarianism to feminism-which the South found so threatening. Perhaps these anxieties might best be defined as the product of conflicts between the sacred and the profane, tensions created by the modernization and secularization of society. The language of slavery, with its close relation to questions of hierarchy and social order, provided a metaphorical framework within which Americans of all sections sought to explore problems central to a society undergoing rapid change. The meaning of both pro- and antislavery thought thus assumed significance well beyond the slavery controversy and served to express anxieties not directly correlated with residence north or south of the Mason-Dixon Line.

Like the Puritan jeremiads Perry Miller has so sensitively explained, the proslavery argument was designed to resolve ambivalence about change which its authors both desired and abhorred. ${ }^{30}$ For the Southern intellectual the defense of slavery served simultaneously to affirm traditional values and to provide a means for advancement in an increasingly dynamic modern world. The invocation of sacred principles reduced tensions arising from their abandonment as absolute criteria for behavior and at the same time provided meaning and cognitive stability to individuals in a world beset by change. Southern thinkers thus sought to revitalize their region by providing it with a conventionalized formula of selfaffirmation founded in a reassuring cosmology. By presenting the proslavery argument as a comprehensive moral and social philosophy they hoped to translate the dilemmas they faced as intellectuals and those the South confronted as a civilization into the same transcendent religious and cultural terms. As men of mind, they were convinced that both their own problems and those of their culture had to be solved within this realm of belief and values. Their transformation of soil exhaustion into moral corruption, of slavery into stewardship, forcefully represented the at-

${ }^{30}$ Miller has written that the jeremiads "constitute a chapter in the emergence of the capitalist mentality, showing how intelligence copes with . . . a change it simultaneously desires and abhors." The New England Mind: From Colony to Province (Cambridge, Mass.: Harvard Univ. Press, 1953), 40. For a more recent discussion of the function of the jeremiad see Sacvan Bercovitch, "Horologicals to Chronometricals: The Rhetoric of the Jeremiad," Literary Monographs, 3 (1970), 1-124, 187-215. 
tempt to deal with what sociologists have defined as the intellectuals' perpetual quandary: the need both to accept and to transcend their tradition and social context.

Throughout the history of the South, this universal intellectual plight has assumed particular poignancy. Thinking Southerners from Thomas Jefferson to C. Vann Woodward have felt compelled by the intensity of both their love and hate for their region to explore the sources of this ambivalence. The proslavery argument represented one such effort simultaneously to justify and reform, but the nature of Southern intellectual life of the past two centuries has made it far from unique. In the absence of highly developed institutions for intellectual life and support, Southern men of mind have had to rely almost exclusively on emotional and psychological, rather than structural ties with their culture. In what H. L. Mencken called the "Sahara of the Bozarts," it has always been difficult for a writer or scholar to ignore the issue of his position within his culture, for he has almost never occupied a well-defined niche which would obviate the need for constant scrutiny of the relationship between himself and his surroundings. Moreover, the uncertainties inherent in this sort of interaction between mind and society have been exacerbated in every era by the persistent issue of race and the difficulties of reconciling the transcendent humanistic values of intellectual commitment with the existing social and racial order. ${ }^{31}$

The nature of the intellectual's adjustment to these particularly Southern problems has varied from generation to generation, but a remarkable consistency pervades all time periods. Thinking Southerners have found themselves like Quentin Compson in William Faulkner's Absalom! Absalom seeking to understand their past in order to transcend it, yet often discovering themselves more the victims than the authors of history. Jefferson instinctively condemned human bondage, yet found in the record of its American origins a kind of inevitability that offered no escape from slaveholding, either for Jefferson himself or his culture. The nineteenthcentury proslavery theorists could seek change and reform in cultural values only by accepting and defending the institution that made such change all but impossible. Half a century later, Thomas Watson nobly undertook a social and racial revolution, but ultimately settled for an embittered racism as the prerequisite for any effort at social change. Twentieth-century Southerners have continued to try to free themselves from these ironies, to make their history less a burden than an opportunity, to enlist Southern tradition in the service of progress. Faulkner,

${ }^{31}$ H. L. Mencken, The Vintage Mencken, Alistair Cooke, ed., (New York: Vintage Books, 1955). 
Robert Penn Warren, and others transformed this effort into a Southern Literary Renaissance, and academic Southern historians have undertaken a related task. C. Vann Woodward, who had chronicled the tragedy of Tom Watson's life, himself sought in the era following Brown v. Board of Education to heighten Southern awareness of the positive aspects of its interracial past in order to use tradition as the foundation for black and white cooperation in a new desegregated era. ${ }^{32}$

The proslavery argument should therefore seem neither an aberration nor a puzzle to the historian. Its contradictions represent those dilemmas confronted by all intellectuals who seek to be at once relevant and transcendent, to serve both their own society and timeless intellectual values, to make their ambitions and convictions coincide. Yet the particular structure of Southern intellectual life and the ever-present moral burden of race have made these chronic problems especially acute. The proslavery argument thus symbolizes both the universality and the peculiarity of the Southern experience. It is a product of feelings of marginality and alienation that have plagued intellectuals throughout history, but it is at the same time an episode in the continuing struggle of Southern thinkers and writers to deal with the particular burden of Southern tradition. The proslavery writers would have understood very well Quentin Compson's desperate need to convince himself that he did not hate the South. ${ }^{33}$

${ }^{32}$ William Faulkner, Absalom, Absalom! (1936; rpt. New York: Random House, 1964); John C. Miller, Wolf by the Ears: Thomas Jefferson and Slavery (New York: Free Press, 1977); C. Vann Woodward, Tom Watson: Agrarian Rebel (New York: Macmillan Co., 1938); C. Vann Woodward, The Strange Career of Jim Crow (New York: Oxford Univ. Press, 1955).

${ }^{33}$ Faulkner, 378. 